\title{
Nutritional Status and the Critically Ill Patient: Gut Microbiota and Immuno-Nutrition in I.C.U. at the Time of SARS-COV 2 Pandemic
}

\author{
Emidio Scarpellini ${ }^{1,2, * \mathbb{D}}$, Laura Scarcella ${ }^{3} \mathbb{D}$, Giorgio Romanelli $^{1}$, Martina Basilico ${ }^{1}$, Emiliano Lattanzi ${ }^{1}$, \\ Carlo Rasetti ${ }^{1}$, Ludovico Abenavoli ${ }^{4}$ (D) and Pierangelo Santori ${ }^{1}$
}

1 Clinical Nutrition Unit and Internal Medicine Unit, "Madonna del Soccorso" General Hospital, 63074 San Benedetto del Tronto, Italy; giorgio.romanelli.gr88@gmail.com (G.R.); martinabasilico82@gmail.com (M.B.); emilianolattanzi20@gmail.com (E.L.); bonimv@libero.it (C.R.); pierangelo.santori@sanita.marche.it (P.S.)

2 Translational Research in GastroIntestinal Disorders (T.A.R.G.I.D.), Gasthuisberg University Hospital, 3000 Leuven, Belgium

3 I.C.U. Unit, “Santa Maria” Hospital, Viale Tristano di Joannuccio, 05100 Terni, Italy; laura.scarcella@yahoo.it

4 Department of Health Sciences, University Magna Graecia, Campus "Salvatore Venuta", 88100 Catanzaro, Italy; 1.abenavoli@unicz.it

* Correspondence: scarpidio@gmail.com; Tel.: +39-0735793304; Fax: +39-0735793306

Citation: Scarpellini, E.; Scarcella, L.; Romanelli, G.; Basilico, M.; Lattanzi, E.; Rasetti, C.; Abenavoli, L.; Santori, P. Nutritional Status and the Critically Ill Patient: Gut Microbiota and Immuno-Nutrition in I.C.U. at the Time of SARS-COV 2 Pandemic. Gastroenterol. Insights 2021, 12, 259-269. https://doi.org/ $10.3390 /$ gastroent 12020022

Academic Editors: Julio Plaza-Díaz and Emanuele Rinninella

Received: 1 April 2021

Accepted: 15 May 2021

Published: 18 May 2021

Publisher's Note: MDPI stays neutral with regard to jurisdictional claims in published maps and institutional affiliations.

Copyright: (c) 2021 by the authors. Licensee MDPI, Basel, Switzerland. This article is an open access article distributed under the terms and conditions of the Creative Commons Attribution (CC BY) license (https:// creativecommons.org/licenses/by/ $4.0 /)$.

\begin{abstract}
Background: Gut microbiota is a complex ecosystem of bacteria, viruses, archaea, protozoa and yeasts in our intestine. It has several functions, including maintaining human body equilibrium. Microbial "dysbiosis" can be responsible for outbreak of local and systemic infections, especially in critically ill patients. Methods: to build a narrative review, we performed a Pubmed, Medline and EMBASE search for English language papers, reviews, meta-analyses, case series and randomized controlled trials (RCTs) by keywords and their associations: critically ill patient; nutrition; gut microbiota; probiotics; gut virome; SARS-COV 2. Results: Over the antibiotic-based "selective decontamination", potentially responsible for drug-resistant microorganisms development, there is growing interest of scientists and the pharmaceutical industry for pre-, probiotics and their associations as safe and reliable remedies restoring gut microbial "eubiosis". Very first encouraging evidences link different gut microbiota profiles with SARS-COV 2 disease stage and gravity. Thus, there is frame for a probiotic therapeutic approach of COVID-19. Conclusions: gut microbiota remodulation seems to be a promising and safe therapeutic approach to prevent local and systemic multi-resistant bug infections in the intensive care unit (ICU) patients. This approach deserves more and more attention at the time of SARS-COV 2 pandemic.
\end{abstract}

Keywords: critically ill patient; nutrition; gut microbiota; probiotics; gut virome; SARS-COV 2

\section{Introduction}

SARS-COV 2 pandemic has brought our attention to the critically ill patient and its management. A complete and accurate nutritional assessment can contribute to its prognosis [1]. Although there is a debate over methods of nutritional status measurement, indirect calorimetry seems to be the gold-standard in these patients [2].

An early enteral (24-48 h upon admission) vs. parenteral nutrition seems to be the best approach for a prompt and better recovery of intensive care unit (ICU) patients [3]. However, there are not yet striking evidences supporting the benefits of immune-nutrition in these patients, in terms of morbidity/mortality. The latter is often linked to the development of systemic infections such as sepsis of pulmonary, venous and, last but not least, gastrointestinal origin. In fact, colonization of the gastrointestinal tract by potentially pathogenic bacteria is common and often precedes clinical infections [3]. Although the 
usage of antibiotics is a well-established measure to rule down the outbreak of those infections, they are effective only in the short term. Furthermore, traditional antibiotic-based decolonization methods may increase the development of microbial resistance in the short and long term [4]. Therefore, scientists have the duty to find novel methods for systemic infections preventions.

Preliminary evidences from this last-year literature on SARS-COV 2 have highlighted the role of the gut microbiota and its modulation in critically ill patients. For example, this may have significant prognostic implications in terms of SARS-COV 2 viral load control and morbidity/mortality [5].

Thus, the aim of this narrative review of literature is to report evidences on the role of gut microbiota modulation through diet and pre-/probiotics in critically ill patients in order to avoid the development of detrimental complications such as systemic infections at the time of SARS-COV 2 pandemic.

\section{Materials and Methods}

We conducted a Pubmed, Medline and EMBASE search for English language papers, reviews, meta-analyses, case series and randomized controlled trials (RCTs) since 1985 until the end of 2020, using the following keywords and their associations: critically ill patient; nutrition; gut microbiota; probiotics; gut virome; SARS-COV 2.

We also included preliminary evidence from abstracts belonging to main national and international Gastroenterological meetings (e.g., F.I.S.M.A.D. National Congress, S.I.N.P.E. National Congress, E.S.P.E.N. annual congress, United European Gastroenterology Week, Digestive Disease Week). The search was conducted by E.S., L.S. and G.R. and independently verified by C.R. and P.S.

\section{Results}

\subsection{Gut Microbiota Composition in Health and Critically Ill Patient}

The human gut microbiota consists of 1014 resident microorganisms, including bacteria, archaea, protozoa, viruses and fungi [6]. The main bacterial phyla in healthy individuals are represented by: Actinobacteria, Firmicutes, Proteobacteria and Bacteroidetes [7]; the main families are: Bacteroidaceae, Prevotellaceae, Rikenellaceae, Lachnospiraceae and Ruminococcaceae [8]. Gut microbiota main functions are: absorptive and digestive; metabolic, with its crucial role in regulation of energy harvesting and expenditure; immune-modulator as it is implicated in the development and maintenance of gut associated (namely, GALT) and systemic immune system's balance equilibrium; ageing and senescence regulator [9].

Upon admission to the ICU, patient gut microbiota is characterized by a dramatic loss of phylogenetic diversity (e.g., reduction of lactobacilli, bifidobacteria) with the growth of pathogenic organisms (e.g., Clostridium difficile (more recently reclassified as Clostridioides difficile), Pseudomonas aeruginosa, Candida species, vancomycin-resistant enterococci (VRE) and multidrug resistant organisms (MDRO)) [10,11].

More in detail, about $4-11 \%$ of all patients in the ICU have intestinal colonization by methicillin-resistant Staphylococcus aureus (MRSA), VRE or multi-drug resistant (MDR) Gram-negative bacteria. Interestingly, an additional $12-14 \%$ of patients free of MDROs at admission becomes colonized [12]. Subsequently, gastrointestinal colonization with MDROs increases risk for subsequent clinical infections of 10-fold [13]. Thus, mortality rates are high with MDR infection causing up to 9 deaths for every 100 patients admitted to the ICU [14].

Another example of the way the gut colonization by pathogenic species can directly affect mortality in ICU patients is resembled by those of Candida species (e.g., C. albicans, C. glabrata, C. parapsilosis, C. krusei and C. tropicalis). This bug spread can occur in up to $80 \%$ of ICU patients [15]. Although the percentage of colonized ICU patients who later develop invasive candidiasis is low, the associated mortality from invasive fungemia ranges from $5 \%$ to $71 \%[16]$. 
Development of sepsis, one of the main causes of ICU admission, in turn, may affect the gut microbiota composition through several mechanisms: endogenous catecholamine production, gut hypoperfusion, disruption of the intestinal mucus layer and decreased bile salt production until small and colonic bacterial overgrowth $[17,18]$.

Use of large-spectrum antibiotics contributes itself to the concept of "dysbiosis" in the frame of gut microbiota. Indeed, the use of these compounds can determine the proliferation of pathogenic bacteria vs. commensal-ones [19]. In addition, broad-spectrum antibiotic use can allow the proliferation of resistant bacteria of new-origin or already present in the gut [20]. Furthermore, there is an increased dissemination of these bacteria into the ICU environment via contact with healthcare workers, adjacent patients or contaminated objects [21]. Other operations typical of ICU patients, potentially responsible for gut dysbiosis, are proton pump inhibitors usage and enteral feeding or delayed enteral feeding [20].

\subsection{Classical and Emerging Gut Microbiota Modulations in Critically Ill Patient}

\subsubsection{Antimicrobials}

Traditional approach to prevent gut dysbiosis as a source of local and/or systemic infections has been represented by "gut decontamination" since the 1980s [22]. Gut decontamination, namely "selective gut decontamination" (SDD), consists of prophylactic administration of oropharyngeal/enteral antimicrobials and of a 4-day course of parenteral antibiotics upon ICU admission [22]. This decontamination is ideally targeted towards potential pathogens such as aerobic Gram-negatives, Staphylococcus aureus and yeasts. On the other hand, this approach was thought to minimize perturbation to endogenous, anaerobic microflora [23]. Some high-quality randomized trials (RCTs) showed SDD to be effective in reducing ICU-acquired infections by pathogens with some promising mortality benefit [22]. Although these findings are controversial, the main benefit is the reduced overall use of antibiotics in the ICU [23].

The main concern to use this SDD approach in the ICU is represented by some evidences that the selective pressure of antibiotics can lead to the emergence of new resistance. Indeed, rebound increases in resistant pathogens after SDD have been demonstrated in several studies [24] (Table 1).

\subsubsection{Nutrition}

There are no large multicenter data supporting the use of nutrition and/or immunenutrition in prevention/treatment of gut microbiota derangements. There are, just, promising evidences supporting the positive impact of early enteral feeding (within 24-48 h) on ICU admission in terms of morbidity/mortality of these patients [3]. More in detail, there are just weak evidences on the efficacy of enteral vs. parenteral nutrition to be associated with a lower risk of infections in the ICU patient [25]. Thus, large prospective ICU trials studying the exact duration, composition (e.g., immune-nutrition vs. classical feeding schemes) of enteral nutrition and its impact on gut microbiota and MDROs infections are lacking (Table 1).

\subsubsection{Prebiotics}

Prebiotics are non-digestible dietary components (e.g., oligosaccharides, fiber and inulin) that promote the proliferation of commensal gut microbiota with beneficial effects on health [26]. We could expect a beneficial effect on gut commensal microbiota in ICU patients with an improved resistance to colonization by detrimental bugs. In addition, prebiotics increase the enteric synthesis of short-chain fatty acids (SCFAs), the main "fuel" for healthy enterocytes.

In detail, a descriptive, observational multicenter study on critically ill patients with sepsis was conducted over a 6-months period vs. matched controls, paired by age and sex. SCFAs stool concentrations were determined in both groups. Propionic acid, acetic acid, butyric acid and isobutyric acid levels were significantly lower in the critically ill patient 
group vs. controls. However, no significant association with complications occurrence, ICU length of stay and discharge conditions was found. Indeed, ICU patients diagnosed with an infection upon admission showed significantly decreased levels of butyric and isobutyric acids vs. other groups $(p<0.05)$ [27].

Table 1. Available approaches for gut microbiota modulation in critically ill patient without and with COVID-19.

\begin{tabular}{|c|c|c|c|}
\hline Patient Category & Advantages & Disadvantages & Grade of Evidence \\
\hline \multicolumn{4}{|l|}{ Critically Ill Patient } \\
\hline $\begin{array}{c}\text { Nutrition and } \\
\text { immuno-nutrition } \\
\text { (e.g., early enteral feeding) }\end{array}$ & $\begin{array}{c}\text { Positive impact of early } \\
\text { enteral feeding in terms of } \\
\text { morbidity/mortality of ICU } \\
\text { patients }\end{array}$ & $\begin{array}{l}\text { Weakness of very first } \\
\text { evidences; no data on impact } \\
\text { of early enteral feeding } \\
\text { (immuno-nutrition) vs. } \\
\text { parenteral on gut microbiota } \\
\text { and MDROs infections }\end{array}$ & Very weak \\
\hline $\begin{array}{c}\text { Antibiotics use } \\
\text { (namely, selective gut } \\
\text { decontamination) }\end{array}$ & $\begin{array}{c}\text { Reduction of ICU-acquired } \\
\text { infections by pathogens, mild } \\
\text { mortality reduction }\end{array}$ & & Weak \\
\hline $\begin{array}{c}\text { Prebiotics } \\
\text { (e.g., Fiber, inulin, } \\
\text { Oligosaccharides) }\end{array}$ & $\begin{array}{c}\text { Non alive micro-organisms, } \\
\text { safe, easy way of } \\
\text { administration, cheap }\end{array}$ & Dose-finding often missing; & Weak \\
\hline $\begin{array}{l}\text { Probiotics } \\
\text { (e.g., Lactobacillus } \\
\text { rhamnosus, } \\
\text { L. casei, L. } \\
\text { plantarum, } \\
\text { Bifidobacterium } \\
\text { Bifidum) }\end{array}$ & $\begin{array}{l}\text { Appear safe in the } \\
\text { ICU, a few side effects } \\
\text { and interactions } \\
\text { with other medications; } \\
\text { increase of innate immunity }\end{array}$ & $\begin{array}{l}\text { Not standardized composition } \\
\text { and/or major efficacy of one } \\
\text { strain vs. others; } \\
\text { Interactions of consensual } \\
\text { antibiotics used; } \\
\text { Possible activation to } \\
\text { pathogens in } \\
\text { immuno-compromised } \\
\text { patients }\end{array}$ & Weak \\
\hline \multicolumn{4}{|l|}{$\begin{array}{l}\text { Critically Ill Patient with } \\
\text { SARS-COV } 2 \text { Infection }\end{array}$} \\
\hline $\begin{array}{c}\text { Nutrition and } \\
\text { immuno-nutrition } \\
\text { (e.g., early enteral feeding) }\end{array}$ & $\begin{array}{l}\text { Same evidences as for non } \\
\text { COVID-19 patients; very first } \\
\text { use of nutrition }\end{array}$ & $\begin{array}{l}\text { Lack of direct evidences on } \\
\text { enteral vs. immuno-nutrition } \\
\text { and vs. parenteral nutrition }\end{array}$ & Very weak \\
\hline $\begin{array}{l}\text { Antibiotics use } \\
\text { (namely, selective gut } \\
\text { decontamination) }\end{array}$ & $\begin{array}{l}\text { Same evidences as for non } \\
\text { COVID-19 patients }\end{array}$ & Lack of direct evidences & Weak \\
\hline $\begin{array}{c}\text { Prebiotics } \\
\text { (e.g., Fiber, inulin, } \\
\text { Oligosaccharides) }\end{array}$ & $\mathrm{N} / \mathrm{A}$ & Lack of direct evidences & Very weak \\
\hline $\begin{array}{c}\text { Probiotics } \\
\text { (e.g., bifdobacteria and } \\
\text { lactobacilli, Streptococcus } \\
\text { thermophilus) }\end{array}$ & $\begin{array}{l}\text { Higher survival rate and a } \\
\text { lower need for ICU; } \\
\text { significant prompt reduction } \\
\text { of asthenia, pyrexia, cough, } \\
\text { dyspnea, diarrhea and } \\
\text { myalgia; } \\
\text { reduction of GI symptoms; } \\
\text { reduced SARS-COV } 2 \\
\text { transmission; increased } \\
\text { antiviral immune-response }\end{array}$ & $\mathrm{N} / \mathrm{A}$ & Weak but promising \\
\hline
\end{tabular}

List of abbreviations: ICU: intensive care unit; MDRO: multi-drug resistant organisms; GI: gastro-intestinal.

Very interestingly, another action of prebiotics on gut microbiota modulation is resembled by the anti-inflammatory effect of their administration. In fact, a recent animal study found prebiotics to be able to reduce the response to pathogen-induced kinase activation in intestinal epithelial cells and to dampen the inflammatory response to lipopolysaccha- 
ride (LPS) in vivo [28]. Moreover, there are evidences that non-digestible oligosaccharides influence B-cell responses and macrophage markers in mice, independently from microbiome $[28,29]$. In humans, an interesting retrospective study considered 129 ICU patients supplemented with fibers and showing significant production of SCFAs, able to maintain gut microbiota stability towards harmful pathogens growth/attempts of colonization [30]. In another small single-center study, adult ICU patients starting enteral nutrition with a formula containing fibers were randomized to either $7 \mathrm{~g} /$ day of additional oligofructose/inulin, able to stimulate bifidobacteria growth in the feces or placebo (namely, maltodextrin). Fresh fecal samples were collected both at baseline and at least after 7 days of supplementation. Twenty-two patients completed the study, showing no significant differences in the concentrations of bifidobacteria between groups. Consequently, there were no differences in fecal concentrations of SCFAs, daily fecal score or incidence of diarrhea between groups. However, there were significantly lower concentrations of Faecalibacterium prausnitzii and Bacteroides-Prevotella in patients receiving additional oligofructose/inulin [31].

Indeed, these evidences are not uniform, showing different or controversial grading of positive effects [29].

Looking at the real-time impact of prebiotics supplementation to ICU patients, there is no compelling evidence that prebiotics can beneficially affect their morbidity/mortality. In a single-blind randomized trial, administration of a high-protein formula enriched with arginine, fiber and antioxidants to 237 ICU patients was not associated with a reduced rate of mortality. However, a lower incidence of catheter-related sepsis was recorded in the intervention group ( 0.4 episodes/1000 ICU days vs. controls' 5.5 episodes/1000 ICU days) [32]. In another study, 30 patients were studied comparing early enteral nutrition with prebiotic in ICU patients with severe pancreatitis vs. standard enteral feeding: there was a reduction in hospital stay and lower rates of complications occurrence (e.g., multiorgan failure, sepsis and death) [33].

Finally, the impact of prebiotics on gut microbiota colonization by pathogens has not been yet investigated in ICU patients (Table 1).

\subsubsection{Probiotics}

Probiotics are live, ingestible microorganisms beneficially affecting host health [34]. Probiotics can be able to prevent gut microbiota colonization by multi (or not)-drugresistant pathogens through: competition, modulation of gut $\mathrm{pH}$, enhancement of innate and adaptive immunity and direct production of antimicrobial substances $[20,35]$. There are solid data from systematic reviews and meta-analyses supporting the beneficial effects of probiotics in critically ill patients [36]. In detail, probiotics administration has been associated with reduced incidence of overall infections, and, in particular, ventilatorassociated pneumonia [37].

Major RCTs (patients' range 48-208) have studied the effects of Lactobacillus-based probiotics on gut colonization in adult ICU patients. The effects of a probiotic drink containing $5 \times 10^{7}$ colony-forming units (CFU) per ml of Lactobacillus plantarum on microbial gastric colonization at days 1, 4 and 8 upon ICU admission and on intestinal permeability, endotoxin exposure, inflammatory marker levels and overall sepsis morbidity and mortality were studied in 103 patients [38]. The probiotic administration showed significantly lower interleukin-6 levels at day 15 vs. controls, without any effect on gastric colonization.

The effect of L. plantarum 299v on Clostridioides difficile colonization was tested in 48 ICU patients: around $19 \%$ of control patients developed C. difficile infection by ICU discharge vs. no-one in the probiotic group [39]. Further, a more recent study with $L$. casei drink administration found a trend of lower rates of antibiotic-associated diarrhea and $C$. difficile infections among ICU patients under antibiotics vs. controls [40]. These findings are corroborated by several systematic reviews and meta-analyses [41]. About other infections prevention, there are interesting results with L. rhamnosus. During their 
ICU stay, 208 patients were randomized to either to L. casei rhamnosus $\left(10^{9} \mathrm{CFU}\right)$ or placebo via nasogastric tube from day 3 upon admission until discharge or exitus. The probiotictreated group had a significant delay in respiratory Pseudomonas aeruginosa colonization (namely, 50 vs. 11 days) [42]. A multistrain probiotic capsule (containing L. rhamnosus GG, L. casei, L. acidophilus and Bifidobacterium bifidum) vs. placebo was tested in 167 ICU patients mechanically ventilated resulting in no significant differences in mortality, colonization or hospital-acquired infections incidence but reduced rate of catheter-related bloodstream infections (namely, $1.8 \%$ of catheter infection days in the treatment vs. $6.8 \%$ of the control group). Intriguingly, severely septic patients treated with probiotics had a threefold reduction in 28-day mortality vs. placebo group. On the other hand, there was an equal increased risk for 90-day mortality in non-severely septic patients receiving probiotics [43].

It is noteworthy to mention evidences from non-ICU patients showing different efficacy of several probiotic strains, potentially usable in the ICU ward. In a small, singlecenter, double-blind RCT, yogurt containing L. rhamnosus GG successfully eradicated VRE carriage in renal ward patients after 4-week. In addition, all remaining patients in the control arm were then crossed to receive the probiotic with a clearance of VRE at 8 weeks control-point. However, these results could have been biased by greater antibiotics use in the probiotic arm [44]. Eighty Swedish patients were randomized to a multi-strain probiotic mixture (mainly, Lactobacillus and Bifidobacterium), without a significant eradication of extended spectrum beta-lactamase(ESBL)-E. coli over placebo for at least 3 months [45] (Table 1).

These studies in critically ill patients, altogether, do not definitively demonstrate a significant impact on gut pathogens colonization as they are variegate, small sample-size and evaluate different variables describing the incidence and prevalence of gut microbiota derangement and infections in ICU.

\subsubsection{Beyond Probiotics: Fecal Microbiota Transplantation (FMT)}

FMT resembles the most direct approach to restore gut dysbiosis currently available in clinical and experimental practice. It consists in the infusion of feces from a healthy donor directly to the gastrointestinal tract of the recipient, restoring both the complexity and diversity of the gut microbiota [46-48]. From a bench point of view, FMT has also been associated with a reduction of antimicrobial resistance genes in stool microbiota [49].

Several systematic reviews and meta-analyses have shown FMT being able to successfully treat recurrent clostridium difficile infection (CDI), with a cure rate of almost $90 \%$. Furthermore, the guidelines indicate FMT to be used in patients with at least two episodes of recurrence, both in mild and severe CDI infections, refractory to initial antibiotic treatment (namely, metronidazole and/or vancomycin) [50,51].

In the frame of ICU infection treatment, FMT, largely considered as a possible intervention to "reset" the gut microbiome, has been shown to do not effectively prevent pathogen colonization. From a systematic revision of FMT studies and case reports with primary end-point the antibiotic-resistant organism decolonization and, others with decolonization as a secondary endpoint, FMT is able to eradicate colonization by various types of MDROs. However, these studies have several drawbacks such as a lack of controls and long-term safety data [52].

In real-life, only a small handful of reports from clinical experience support the use of FMT in ICU patients [53]. Finally, while FMT is reasonably safe, high-profile cases of bacteremia have been reported [54].

\subsection{Potential Gut Microbiota Modulation in Critically Ill Patient with SARS-COV 2}

SARS-COV 2 viral RNA has been first detected in the respiratory secretions and, then, stool of COVID-19 patients after onset of disease until more than one month thereafter [55]. In addition, some patients have diarrhea, suggesting a possible gut microbiota derangement, and, further, justifying a possible involvement of "gut-lung axis" in this disease features [56]. 
Over the notable and wide evidences on gut microbiota, lung has its own "microbiota" [57]. While in the gut Bacteroidetes and Firmicutes are predominant, Bacteroidetes, Firmicutes and Proteobacteria are the most represented in the lung [58].

The "gut-lung axis" is a pathophysiological bidirectional model involved in the pathogenesis of several pulmonary diseases. Specifically, endotoxins (e.g., bacterial lypopolisaccharide (LPS)), microbial metabolites of gut origin can reach the lung through the bloodstream, bringing to the inflammation of the lung tissues and, in a circle, back to the intestine [58]. Thus, it is conceivable that the novel SARS-Cov2 might affect the gut microbiota such as in other interstitial and non-interstitial lung diseases [59]. In fact, several experimental animals/human models and clinical observations have suggested that the gut microbiota plays a key role in the pathogenesis of sepsis and acute respiratory distress syndrome (ARDS) [60,61].

In the case of COVID-19 patients, Ruminococcus gnavus was found to have a positive correlation with inflammatory response. On the other hand, Clostridia spp. showed a negative correlation [62]. Interestingly, a strong association was demonstrated between the severity of COVID-19 in the elderly and such bugs and the blood proteomics risk score (PRS). PRS resembled microbiome-driven modifications of proteins due to inflammation [63]. Further, as SARS-CoV-2 S glycoprotein binds to human angiotensin converting enzyme-2 (ACE)2 receptor, an almost ubiquitous enzyme receptor in our body, expressed in esophageal and intestinal epithelial cells and lung tissues, this could be another link that justify the "dysbiosis" of gut microflora and related gastrointestinal symptoms of COVID-19 [64].

The potential use of probiotics as prophylactic or therapeutic remedies for COVID-19 arises from evidences based on sequencing of gut microbiota SARS-COV 2 infected patients with a significant decrease in bifidobacteria and lactobacilli and the significant increase of the number of opportunistic bacteria such as Corynebacterium or Ruthenibacterium [65]. D'Ettorre et al. investigated the efficacy of oral probiotic formulations containing Streptococcus thermophilus DSM 32345, L. acidophilus DSM 32241, Lactobacillus helveticus DSM 32242, Lactobacillus paracasei DSM 32243, Lactobacillus Plantarum DSM 32244, Lactobacillus brevis DSM 27961, Bifdobacterium lactis DSM 32246 and Bifdobacterium lactis DSM 32,247 as an add-on curative option to prevent the progression of COVID-19 in patients treated with hydroxychloroquine, tocilizumab and antimicrobials alone or in combination, in a randomized manner [66]. Patients receiving also bacteriotherapy had a higher survival rate and a lower need for ICU (namely, lower predicted risk of developing respiratory failure). Moreover, a significant prompt reduction of asthenia, pyrexia, cough, dyspnea, diarrhea and myalgia was observed. The authors hypothesized a potential "immunomodulatory" action of several probiotic strains as the antioxidant pathway nuclear factor erythroid 2p45-related factor 2 (Nrf2) and heme oxygenase-1 (HO-1) were both increased upon probiotics administration. Indeed, these are anti-oxidative and anti-viral acting molecules as it has perhaps been shown for human immunodeficiency virus (HIV), influenza virus (IV), respiratory syncytial virus (RSV), Ebola virus and dengue virus [67].

Interleukin-17 is a pro-inflammatory cytokine with a crucial role in the adaptive immune system, as it is a potent inducer of endoplasmic reticulum stress autophagy through inositol-requiring enzyme $1[17,68]$. By blocking this interleukin, autophagy mediated by endoplasmic reticulum stress and inflammation can be prevented [69]. Interestingly, Bifdobacterium strains are able to inhibit interleukin-17 [58]. Thus, administration of high doses of Bifdobacterium strains (e.g., B. animalis subsp. lactiBB-12) could prevent the inflammatory "storm" of COVID-19, especially in those with gastrointestinal symptoms [70].

Furthermore, Lactobacillus coryniformis CECT5711 K8 has been found to decrease SARS-COV 2 transmission and COVID-19 severity [71] (Table 1).

More interestingly, several metabolites derived from Lactobacillus plantarum, including plantaricin, lactic acid, acetic acid and gamma-aminobutyric acid, can increase the anti-viral immune response [72]. Thus, Anwar et al., using as target the S glycoprotein and ACE2, showed that plantaricin is able to prevent the entry of SARS-CoV-2 into cells [73]. 
All these data support the opportunity to design and use probiotic and postbiotic compounds to prevent SARS-CoV-2 cellular entrance and, thus, the contagions exponential rise (Table 1).

\section{Conclusions and Future Perspectives}

Gut microbiota is one of the main actors of our body physiology and pathophysiology. In the frame of the "fragile" ICU patient, gut dysbiosis represents one important source for bacterial infections also outside our intestine. Despite the use of selective gut decontamination, the use of pre-, pro- and symbiotics represents a safe and reliable remodulatory approach of gut microbiota of critically ill patients, able to prevent antibiotic-resistant bacteria spread.

SARS-COV 2 infection and its disease, COVID-19, are one extraordinary example of application of gut microbiota remodulatory approaches, re-establishing gut "eubiosis" and preventing detrimental systemic infections by potential MDROs.

Author Contributions: Conceptualization: E.S. and L.S. had the original idea of this manuscript; Methodology: G.R., M.B. and E.L. performed the review of literature; Validation: L.A., C.R. and P.S. revised and validated the literature findings; Formal Analysis: E.S. and L.S.; Investigation: E.S., L.S. and L.A.; Data Curation: E.S. and E.L.; Writing_Original Draft Preparation: E.S. and L.S. wrote the paper; Writing-Review \& Editing: E.S., L.S. and L.A.; Visualization: M.B. and E.L.; Supervision: E.S., L.S., C.R. and P.S.; Project Administration: E.S., L.S. and L.A. All authors have read and agreed to the published version of the manuscript.

Funding: This research received no external funding.

Institutional Review Board Statement: Not applicable.

Informed Consent Statement: Not applicable.

Data Availability Statement: Not applicable.

Conflicts of Interest: The authors declare no conflict of interest.

\section{References}

1. Laviano, A.; Koverech, A.; Zanetti, M. Nutrition support in the time of SARS-CoV-2 (COVID-19). Nutrition 2020, 74, 110834. [CrossRef]

2. Barazzoni, R.; Bischoff, S.C.; Breda, J.; Wickramasinghe, K.; Krznaric, Z.; Nitzan, D.; Pirlich, M.; Singer, P.; Endorsed by the ESPEN Council. ESPEN expert statements and practical guidance for nutritional management of individuals with SARS-CoV-2 infection. Clin. Nutr. 2020, 39, 1631-1638. [CrossRef]

3. Singer, P.; Blaser, A.R.; Berger, M.M.; Alhazzani, W.; Calder, P.C.; Casaer, M.P.; Hiesmayr, M.; Mayer, K.; Montejo, J.C.; Pichard, C.; et al. ESPEN guideline on clinical nutrition in the intensive care unit. Clin. Nutr. 2019, 38, 48-79. [CrossRef]

4. Lau, J.S.Y.; Bhatt, S.; Streitberg, R.; Bryant, M.; Korman, T.M.; Woolley, I. Surveillance of life-long antibiotics-A cross-sectional cohort study assessing patient attitudes and understanding of long-term antibiotic consumption. Infect. Dis. Health 2019, 24, 179-186. [CrossRef] [PubMed]

5. Spagnolello, O.; Pinacchio, C.; Santinelli, L.; Vassalini, P.; Innocenti, G.P.; De Girolamo, G.; Fabris, S.; Giovanetti, M.; Angeletti, S.; Russo, A.; et al. Targeting Microbiome: An Alternative Strategy for Fighting SARS-CoV-2 Infection. Chemotherapy 2021, 23, 1-9.

6. Gill, S.R.; Pop, M.; Deboy, R.T.; Eckburg, P.B.; Turnbaugh, P.J.; Samuel, B.S.; Gordon, J.I.; Relman, D.A.; Fraser-Liggett, C.M.; Nelson, K.E. Metagenomic analysis of the human distal gut microbiome. Science 2006, 312, 1355-1359. [CrossRef]

7. Abenavoli, L.; Scarpellini, E.; Colica, C.; Boccuto, L.; Salehi, B.; Sharifi-Rad, J.; Aiello, V.; Romano, B.; De Lorenzo, A.; Izzo, A.A.; et al. Gut Microbiota and Obesity: A Role for Probiotics. Nutrients 2019, 11, 2690. [CrossRef]

8. Hall, A.B.; Tolonen, A.C.; Xavier, R.J. Human genetic variation and the gut microbiome in disease. Nat. Rev. Genet. 2017, 18, 690-699. [CrossRef] [PubMed]

9. Rinninella, E.; Raoul, P.; Cintoni, M.; Franceschi, F.; Miggiano, G.A.D.; Gasbarrini, A.; Mele, M.C. What is the Healthy Gut Microbiota Composition? A Changing Ecosystem across Age, Environment, Diet, and Diseases. Microorganisms 2019, 7, 14. [CrossRef] [PubMed]

10. Liu, W.; Cheng, M.; Li, J; Zhang, P.; Fan, H.; Hu, Q.; Han, M.; Su, L.; He, H.; Tong, Y.; et al. Classification of the Gut Microbiota of Patients in Intensive Care Units During Development of Sepsis and Septic Shock. Genom. Proteom. Bioinform. 2021. [CrossRef] [PubMed]

11. Zaher, S. Nutrition and the gut microbiome during critical illness: A new insight of nutritional therapy. Saudi J. Gastroenterol. 2020, 26, 290. [CrossRef] [PubMed] 
12. Burillo, A.; Muñoz, P.; Bouza, E. Risk stratification for multidrug-resistant Gram-negative infections in ICU patients. Curr. Opin. Infect. Dis. 2019, 32, 626-637. [CrossRef] [PubMed]

13. Iordanou, S.; Palazis, L.; Timiliotou-Matsentidou, C.; Mendris, M.; Raftopoulos, V. When Multidrug-Resistant Organism (MDRO)Positive ICU Patient Isolation and Cohorting Is Not Feasible, What Comes Next? Cureus 2021, 13, e13636. [PubMed]

14. Vincent, J.L.; Rello, J.; Marshall, J.; Silva, E.; Anzueto, A.; Martin, C.D.; Moreno, R.; Lipman, J.; Gomersall, C.; Sakr, Y.; et al. International study of the prevalence and outcomes of infection in intensive care units. JAMA 2009, 302, 2323-2329. [CrossRef] [PubMed]

15. Eggimann, P.; Garbino, J.; Pittet, D. Epidemiology of Candida species infections in critically ill non-immunosuppressed patients. Lancet Infect. Dis. 2003, 3, 685-702. [CrossRef]

16. Quindós, G. Epidemiology of candidaemia and invasive candidiasis. A changing face. Rev. Iberoam. Micol. 2014, 31, 42-48. [CrossRef]

17. Liu, Z.; Li, N.; Fang, H.; Chen, X.; Guo, Y.; Gong, S.; Niu, M.; Zhou, H.; Jiang, Y.; Chang, P.; et al. Enteric dysbiosis is associated with sepsis in patients. FASEB J. 2019, 33, 12299-12310. [CrossRef]

18. Wang, C.; Li, Q.; Ren, J. Microbiota-Immune Interaction in the Pathogenesis of Gut-Derived Infection. Front. Immunol. 2019, 10, 1873. [CrossRef]

19. Freedberg, D.E.; Zhou, M.J.; Cohen, M.E.; Annavajhala, M.K.; Khan, S.; Moscoso, D.I.; Brooks, C.; Whittier, S.; Chong, D.H.; Uhlemann, A.C.; et al. Pathogen colonization of the gastrointestinal microbiome at intensive care unit admission and risk for subsequent death or infection. Intensive Care Med. 2018, 44, 1203-1211. [CrossRef]

20. Choy, A.; Freedberg, D.E. Impact of microbiome-based interventions on gastrointestinal pathogen colonization in the intensive care unit. Ther. Adv. Gastroenterol. 2020, 13, 1756284820939447. [CrossRef]

21. Blake, K.S.; Choi, J.; Dantas, G. Approaches for characterizing and tracking hospital-associated multidrug-resistant bacteria. Cell. Mol. Life Sci. 2021, 78, 2585-2606. [CrossRef]

22. Buelow, E.; Bello González, T.D.J.; Fuentes, S.; de Steenhuijsen Piters, W.A.A.; Lahti, L.; Bayjanov, J.R.; Majoor, E.A.M.; Braat, J.C.; van Mourik, M.S.M.; Oostdijk, E.A.N.; et al. Comparative gut microbiota and resistome profiling of intensive care patients receiving selective digestive tract decontamination and healthy subjects. Microbiome 2017, 15, 88. [CrossRef] [PubMed]

23. Tan, G.S.E.; Tay, H.L.; Tan, S.H.; Lee, T.H.; Ng, T.M.; Lye, D.C. Gut Microbiota Modulation: Implications for Infection Control and Antimicrobial Stewardship. Adv. Ther. 2020, 37, 4054-4067. [CrossRef] [PubMed]

24. Oostdijk, E.A.; de Smet, A.M.; Blok, H.E.; Thieme Groen, E.S.; van Asselt, G.J.; Benus, R.F.; Bernards, S.A.; Frénay, I.H.; Jansz, A.R.; de Jongh, B.M.; et al. Ecological effects of selective decontamination on resistant gram-negative bacterial colonization. Am. J. Respir. Crit. Care Med. 2010, 181, 452-457. [CrossRef] [PubMed]

25. Elke, G.; van Zanten, A.R.; Lemieux, M.; McCall, M.; Jeejeebhoy, K.N.; Kott, M.; Jiang, X.; Day, A.G.; Heyland, D.K. Enteral versus parenteral nutrition in critically ill patients: An updated systematic review and meta-analysis of randomized controlled trials. Crit. Care 2016, 20, 117. [CrossRef] [PubMed]

26. Marco, M.L.; Sanders, M.E.; Gänzle, M.; Arrieta, M.C.; Cotter, P.D.; De Vuyst, L.; Hill, C.; Holzapfel, W.; Lebeer, S.; Merenstein, D.; et al. The International Scientific Association for Probiotics and Prebiotics (ISAPP) consensus statement on fermented foods. Nat. Rev. Gastroenterol. Hepatol. 2021, 18, 196-208. [CrossRef] [PubMed]

27. Valdés-Duque, B.E.; Giraldo-Giraldo, N.A.; Jaillier-Ramírez, A.M.; Giraldo-Villa, A.; Acevedo-Castaño, I.; Yepes-Molina, M.A.; Barbosa-Barbosa, J.; Barrera-Causil, C.J.; Agudelo-Ochoa, G.M. Stool Short-Chain Fatty Acids in Critically Ill Patients with Sepsis. J. Am. Coll. Nutr. 2020, 39, 706-712. [CrossRef]

28. Fransen, F.; Sahasrabudhe, N.M.; Elderman, M.; Bosveld, M.; El Aidy, S.; Hugenholtz, F.; Borghuis, T.; Kousemaker, B.; Winkel, S.; van der Gaast-de Jongh, C.; et al. $\beta 2 \rightarrow 1$-Fructans Modulate the Immune System In Vivo in a Microbiota-Dependent and-Independent Fashion. Front. Immunol. 2017, 16, 154. [CrossRef]

29. Venegas-Borsellino, C.; Kwon, M. Impact of Soluble Fiber in the Microbiome and Outcomes in Critically Ill Patients. Curr. Nutr. Rep. 2019, 8, 347-355. [CrossRef]

30. Fu, Y.; Moscoso, D.I.; Porter, J.; Krishnareddy, S.; Abrams, J.A.; Seres, D.; Chong, D.H.; Freedberg, D.E. Relationship Between Dietary Fiber Intake and Short-Chain Fatty Acid-Producing Bacteria During Critical Illness: A Prospective Cohort Study. JPEN J. Parenter. Enteral Nutr. 2020, 44, 463-471. [CrossRef]

31. Majid, H.A.; Cole, J.; Emery, P.W.; Whelan, K. Additional oligofructose/inulin does not increase faecal bifidobacteria in critically ill patients receiving enteral nutrition: A randomised controlled trial. Clin. Nutr. 2014, 33, 966-972. [CrossRef] [PubMed]

32. Caparrós, T.; Lopez, J.; Grau, T. Early enteral nutrition in critically ill patients with a high-protein diet enriched with arginine, fiber, and antioxidants compared with a standard high-protein diet. The effect on nosocomial infections and outcome. JPEN J. Parenter. Enteral Nutr. 2001, 25, 299-308. [CrossRef] [PubMed]

33. Karakan, T.; Ergun, M.; Dogan, I.; Cindoruk, M.; Unal, S. Comparison of early enteral nutrition in severe acute pancreatitis with prebiotic fiber supplementation versus standard enteral solution: A prospective randomized double-blind study. World J. Gastroenterol. 2007, 13, 2733-2737. [CrossRef] [PubMed]

34. Scarpellini, E.; Fagoonee, S.; Rinninella, E.; Rasetti, C.; Aquila, I.; Larussa, T.; Ricci, P.; Luzza, F.; Abenavoli, L. Gut Microbiota and Liver Interaction through Immune System Cross-Talk: A Comprehensive Review at the Time of the SARS-CoV-2 Pandemic. J. Clin. Med. 2020, 9, 2488. [CrossRef] [PubMed] 
35. Batra, P.; Soni, K.D.; Mathur, P. Efficacy of probiotics in the prevention of VAP in critically ill ICU patients: An updated systematic review and meta-analysis of randomized control trials. J. Intensive Care 2020, 8, 81. [CrossRef] [PubMed]

36. Zhao, J.; Li, L.Q.; Chen, C.Y.; Zhang, G.S.; Cui, W.; Tian, B.P. Do probiotics help prevent ventilator-associated pneumonia in critically ill patients? A systematic review with meta-analysis. ERJ Open Res. 2021, 7, 00302-2020. [CrossRef]

37. Manzanares, W.; Lemieux, M.; Langlois, P.L.; Wischmeyer, P.E. Probiotic and synbiotic therapy in critical illness: A systematic review and meta-analysis. Crit. Care 2016, 19, 262. [CrossRef] [PubMed]

38. McNaught, C.E.; Woodcock, N.P.; Anderson, A.D.; MacFie, J. A prospective randomised trial of probiotics in critically ill patients. Clin. Nutr. 2005, 24, 211-219. [CrossRef]

39. Klarin, B.; Wullt, M.; Palmquist, I.; Molin, G.; Larsson, A.; Jeppsson, B. Lactobacillus plantarum 299v reduces colonisation of Clostridium difficile in critically ill patients treated with antibiotics. Acta Anaesthesiol. Scand. 2008, 52, 1096-1102. [CrossRef]

40. Alberda, C.; Marcushamer, S.; Hewer, T.; Journault, N.; Kutsogiannis, D. Feasibility of a Lactobacillus casei Drink in the Intensive Care Unit for Prevention of Antibiotic Associated Diarrhea and Clostridium difficile. Nutrients 2018, 10, 539. [CrossRef]

41. Goldenberg, J.Z.; Yap, C.; Lytvyn, L.; Lo, C.K.; Beardsley, J.; Mertz, D.; Johnston, B.C. Probiotics for the prevention of Clostridium difficile-associated diarrhea in adults and children. Cochrane Database Syst. Rev. 2017, 12, CD006095. [CrossRef]

42. Forestier, C.; Guelon, D.; Cluytens, V.; Gillart, T.; Sirot, J.; De Champs, C. Oral probiotic and prevention of Pseudomonas aeruginosa infections: A randomized, double-blind, placebo-controlled pilot study in intensive care unit patients. Crit. Care 2008, 2, R69. [CrossRef] [PubMed]

43. Barraud, D.; Blard, C.; Hein, F.; Marçon, O.; Cravoisy, A.; Nace, L.; Alla, F.; Bollaert, P.E.; Gibot, S. Probiotics in the critically ill patient: A double blind, randomized, placebo-controlled trial. Intensive Care Med. 2010, 36, 1540-1547. [CrossRef] [PubMed]

44. Manley, K.J.; Fraenkel, M.B.; Mayall, B.C.; Power, D.A. Probiotic treatment of vancomycin-resistant enterococci: A randomised controlled trial. Med. J. Aust. 2007, 186, 454-457. [CrossRef]

45. Ljungquist, O.; Kampmann, C.; Resman, F.; Riesbeck, K.; Tham, J. Probiotics for intestinal decolonization of ESBL-producing Enterobacteriaceae: A randomized, placebo-controlled clinical trial. Clin. Microbiol. Infect. 2020, 26, 456-462. [CrossRef] [PubMed]

46. Cammarota, G.; Ianiro, G.; Gasbarrini, A. Fecal microbiota transplantation for the treatment of Clostridium difficile infection: A systematic review. J. Clin. Gastroenterol. 2014, 48, 693-702. [CrossRef] [PubMed]

47. Barberio, B.; Facchin, S.; Mele, E.; D’Incà, R.; Sturniolo, G.C.; Farinati, F.; Zingone, F.; Quagliariello, A.; Ghisa, M.; Massimi, D.; et al. Faecal microbiota transplantation in Clostridioides difficile infection: Real-life experience from an academic Italian hospital. Ther. Adv. Gastroenterol. 2020, 13, 1756284820934315. [CrossRef]

48. Aira, A.; Fehér, C.; Rubio, E.; Soriano, A. The Intestinal Microbiota as a Reservoir and a Therapeutic Target to Fight Multi-DrugResistant Bacteria: A Narrative Review of the Literature. Infect. Dis. Ther. 2019, 8, 469-482. [CrossRef]

49. Millan, B.; Park, H.; Hotte, N.; Mathieu, O.; Burguiere, P.; Tompkins, T.A.; Kao, D.; Madsen, K.L. Fecal Microbial Transplants Reduce Antibiotic-resistant Genes in Patients With Recurrent Clostridium difficile Infection. Clin. Infect. Dis. 2016, 62, 1479-1486. [CrossRef]

50. Quraishi, M.N.; Widlak, M.; Bhala, N.; Moore, D.; Price, M.; Sharma, N.; Iqbal, T.H. Systematic review with meta-analysis: The efficacy of faecal microbiota transplantation for the treatment of recurrent and refractory Clostridium difficile infection. Aliment. Pharmacol. Ther. 2017, 46, 479-493. [CrossRef]

51. Tariq, R.; Hayat, M.; Pardi, D.; Khanna, S. Predictors of failure after fecal microbiota transplantation for recurrent Clostridioides difficile infection: A systematic review and meta-analysis. Eur. J. Clin. Microbiol. Infect. Dis. 2021. [CrossRef] [PubMed]

52. Woodworth, M.H.; Hayden, M.K.; Young, V.B.; Kwon, J.H. The Role of Fecal Microbiota Transplantation in Reducing Intestinal Colonization with Antibiotic-Resistant Organisms: The Current Landscape and Future Directions. Open Forum Infect. Dis. 2019, 6, ofz288. [CrossRef] [PubMed]

53. Limketkai, B.N.; Hendler, S.; Ting, P.S.; Parian, A.M. Fecal Microbiota Transplantation for the Critically Ill Patient. Nutr. Clin. Pract. 2019, 34, 73-79. [CrossRef]

54. DeFilipp, Z.; Bloom, P.P.; Torres Soto, M.; Mansour, M.K.; Sater, M.R.A.; Huntley, M.H.; Turbett, S.; Chung, R.T.; Chen, Y.B.; Hohmann, E.L. Drug-Resistant, E. coli Bacteremia Transmitted by Fecal Microbiota Transplant. N. Engl. J. Med. 2019, 381, 2043-2050. [CrossRef] [PubMed]

55. Chan, K.H.; Poon, L.L.; Cheng, V.C.; Guan, Y.; Hung, I.F.; Kong, J.; Yam, L.Y.; Seto, W.H.; Yuen, K.Y.; Peiris, J.S. Detection of SARS coronavirus in patients with suspected SARS. Emerg. Infect. Dis. 2004, 10, 294-299. [CrossRef] [PubMed]

56. Dhar, D.; Mohanty, A. Gut microbiota and Covid-19- possible link and implications. Virus Res. 2020, 285, 198018. [CrossRef]

57. de Oliveira, G.L.V.; Oliveira, C.N.S.; Pinzan, C.F.; de Salis, L.V.V.; Cardoso, C.R.B. Microbiota Modulation of the Gut-Lung Axis in COVID-19. Front. Immunol. 2021, 12, 635471. [CrossRef]

58. Chioma, O.S.; Hesse, L.E.; Chapman, A.; Drake, W.P. Role of the Microbiome in Interstitial Lung Diseases. Front. Med. 2021, 8 , 595522. [CrossRef]

59. Groves, H.T.; Higham, S.L.; Moffatt, M.F.; Cox, M.J.; Tregoning, J.S. Respiratory Viral Infection Alters the Gut Microbiota by Inducing Inappetence. mBio 2020, 11, e03236-19. [CrossRef]

60. Dickson, R.P. The microbiome and critical illness. Lancet Respir. Med. 2016, 4, 59-72. [CrossRef]

61. McDonald, D.; Ackermann, G.; Khailova, L.; Baird, C.; Heyland, D.; Kozar, R.; Lemieux, M.; Derenski, K.; King, J.; Vis-Kampen, C.; et al. Extreme Dysbiosis of the Microbiome in Critical Illness. mSphere 2016, 1, e00199-16. [CrossRef] [PubMed] 
62. Ferreira, C.; Viana, S.D.; Reis, F. Is Gut Microbiota Dysbiosis a Predictor of Increased Susceptibility to Poor Outcome of COVID-19 Patients? An Update. Microorganisms 2020, 9, 53. [CrossRef] [PubMed]

63. Mirzaei, R.; Attar, A.; Papizadeh, S.; Jeda, A.S.; Hosseini-Fard, S.R.; Jamasbi, E.; Kazemi, S.; Amerkani, S.; Talei, G.R.; Moradi, P.; et al. The emerging role of probiotics as a mitigation strategy against coronavirus disease 2019 (COVID-19). Arch. Virol. 2021, 1-22. [CrossRef]

64. Li, M.Y.; Li, L.; Zhang, Y.; Wang, X.S. Expression of the SARS-CoV-2 cell receptor gene ACE2 in a wide variety of human tissues. Infect. Dis. Poverty 2020, 9, 45. [CrossRef] [PubMed]

65. Moradi-Kalbolandi, S.; Majidzadeh-A, K.; Abdolvahab, M.H.; Jalili, N.; Farahmand, L. The Role of Mucosal Immunity and Recombinant Probiotics in SARS-CoV2 Vaccine Development. Probiotics Antimicrob. Proteins 2021. [CrossRef]

66. d'Ettorre, G.; Ceccarelli, G.; Marazzato, M.; Campagna, G.; Pinacchio, C.; Alessandri, F.; Ruberto, F.; Rossi, G.; Celani, L.; Scagnolari, C.; et al. Challenges in the Management of SARS-CoV2 Infection: The Role of Oral Bacteriotherapy as Complementary Therapeutic Strategy to Avoid the Progression of COVID-19. Front. Med. 2020, 7, 389. [CrossRef] [PubMed]

67. Tseng, C.K.; Lin, C.K.; Wu, Y.H.; Chen, Y.H.; Chen, W.C.; Young, K.C.; Lee, J.C. Human heme oxygenase 1 is a potential host cell factor against dengue virus replication. Sci. Rep. 2016, 6, 32176. [CrossRef]

68. Kim, S.R.; Kim, H.J.; Kim, D.I.; Lee, K.B.; Park, H.J.; Jeong, J.S.; Cho, S.H.; Lee, Y.C. Blockade of Interplay between IL-17A and Endoplasmic Reticulum Stress Attenuates LPS-Induced Lung Injury. Theranostics 2015, 5, 1343-1362. [CrossRef]

69. Gackowska, L.; Michalkiewicz, J.; Krotkiewski, M.; Helmin-Basa, A.; Kubiszewska, I.; Dzierzanowska, D. Combined effect of different lactic acid bacteria strains on the mode of cytokines pattern expression in human peripheral blood mononuclear cells. $J$. Physiol. Pharmacol. 2006, 57, 13-21.

70. Schiavi, E.; Gleinser, M.; Molloy, E.; Groeger, D.; Frei, R.; Ferstl, R.; Rodriguez-Perez, N.; Ziegler, M.; Grant, R.; Moriarty, T.F.; et al. The Surface-Associated Exopolysaccharide of Bifidobacterium longum 35624 Plays an Essential Role in Dampening Host Proinflammatory Responses and Repressing Local TH17 Responses. Appl. Environ. Microbiol. 2016, 82, 7185-7196. [CrossRef] [PubMed]

71. Biosearch Life Launches Probiotic COVID-19 Trial, Consumers Move for Gut Health Products. Available online: https://www. nutritioninsight.com/news/biosearch-life-launches-probiotic-covid-19-trial-consumers-move-for-gut-health-products.html (accessed on 10 December 2020).

72. Tiwari, S.K.; Dicks, L.M.T.; Popov, I.V.; Karaseva, A.; Ermakov, A.M.; Suvorov, A.; Tagg, J.R.; Weeks, R.; Chikindas, M.L. Probiotics at War Against Viruses: What Is Missing From the Picture? Front. Microbiol. 2020, 11, 1877. [CrossRef] [PubMed]

73. Anwar, F.; Altayb, H.N.; Al-Abbasi, F.A.; Al-Malki, A.L.; Kamal, M.A.; Kumar, V. Antiviral effects of probiotic metabolites on COVID-19. J. Biomol. Struct. Dyn. 2020. [CrossRef] [PubMed] 